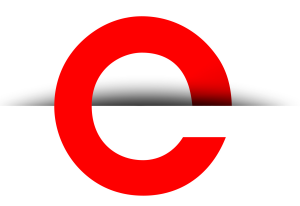

U T S

e PRES S
PORTAL Journal of Multidisciplinary International Studies

Vol. 17, No. 1/2

Jan 2021

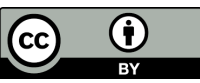

(C) 2021 by the author(s). This is an Open Access article distributed under the terms of the Creative Commons Attribution 4.0 International (CC BY 4.0) License (https:// creativecommons.org/ licenses/by/4.0/), allowing third parties to copy and redistribute the material in any medium or format and to remix, transform, and build upon the material for any purpose, even commercially, provided the original work is properly cited and states its license.

Citation: Duruz, J. 2021 Mourning le Temps Perdu (Proust 1988-1990): Eating Together in Pestilence. PORTAL Journal of Multidisciplinary International Studies, 17:1/2, 110-112. http://dx.doi.org/10.5130/ pjmis.v17i1-2.7326

ISSN 1449-2490 | Published by UTS ePRESS | http://epress. lib.uts.edu.au/ojs/index.php/ portal
CULTURAL WORK

\section{Mourning le Temps Perdu (Proust 1988-1990): Eating Together in Pestilence}

\author{
Jean Duruz \\ Corresponding author: Dr. Jean Duruz, Adjunct Senior Research Fellow, University of South \\ Australia, GPO Box 2471, Adelaide SA 5001, Australia. Jean.DuruzQunisa.edu.au \\ DOI: http://dx.doi.org/10.5130/pimis.v17i1-2.7326 \\ Article History: Received 14/07/2020; Accepted 11/11/2020; Published 28/01/2021
}

\begin{abstract}
This creative piece of non-fiction was written in response to the challenges of everyday life in the early weeks of the pandemic in Australia. I wanted to convey the emotional economy of experiences - the longing, sense of loss, traces of guilt in processes of remembering and storytelling, particularly when these feelings might seem unjustified and selfindulgent.
\end{abstract}

\section{Keywords}

\section{Culture; Everyday life; Emotion; Memory}

I live in a small village called Mile End. It's actually a suburban enclave of the city of Adelaide, South Australia, the village's name referencing its colonial British history (with, for example, Mile End, London and Mile End, Montreal embedded in that same history). My neighbors are Greek, Italian, Vietnamese, Afghani, Ethiopian, Irish, Scottish, German, Chinese, Malaysian and Anglo-Australian (City of West Torrens 2016). We, the lucky ones, live on quarter acre plots carved from fertile river flats, planted with olive trees, pomegranates, lemons, apples, figs, apricots, persimmons, almonds and grape vines. Meanwhile the Mediterranean climate ensures that market gardens, orchards, vineyards and olive groves prosper to the north and south of the city. We have enough food. Remember this.

Enter COVID-19. A few steps from our front gate, the local supermarket (at its best, notably cosmopolitan in its range of offerings) is awash with people, somewhat mysteriously purchasing toilet paper. The shelves quickly empty of this. As well, overnight, pasta, rice, 
U T S

e PRES S passata and tinned tomatoes become coveted items. Understandable, certainly, not only in terms of the presence of elderly Italian neighbors but also common knowledge that spaghetti bolognaise is a ubiquitous comfort dish on Australian dinner tables (Special Broadcasting Service 2013). On the other hand, the panic itself is less understandable. While South Australians have not displayed the checkout violence occurring in other states, rationing of certain products has been introduced. Shopping then becomes a grim affair, as if our lives and livelihoods depended on the size of our stockpiles. Is there not enough food, after all?

The Prime Minister, headmaster-fashion addresses the nation with an injunction against hoarding. 'Stop it!' he barks and accuses hoarders of being 'un-Australian' (ky News 2020). The National Farmers' Federation produces an advertisement with the back view of an iconic suntanned farmer figure (who, interestingly, looks like a woman) with the byline 'Don't panic. We're experts at working from home' (Farm Online 2020). The text continues comfortingly that the nation produces enough food for triple the population (which begs the question why are we exporting our own food and importing others' so much?). However, without resorting to Trumpish Australia-First kinds of arguments, the advertisement concludes 'a food shortage is one thing you don't need to worry about' and that all we need to do is 'shop sensibly.' So, is there plenty of food to go around (even of 'food you love') after all?

If food security is not really the issue, then what is? I want to suggest that, leaving aside fears of the virus itself and its health, economic and social ramifications (people dying, hospitals failing to cope, job losses, families unable to visit each other), there is a miasma of mourning hanging over our cities. The grief is inchoate but acute. A sense of loss, of Proust's temps perdu [lost time]. As I walk through the deserted streets of my neighborhood, I pass the café where almost daily I used to have a piece of torta de spinaci [spinach pie]. The café is, to all intents and purposes, closed with furniture stacked away and no sign of life except for a small takeaway sign. I wonder about the fate of the staff-casuals, students, who are unlikely to benefit from current government rescue packages. At nearby Henley Beach, it seems almost unthinkable to go for my mandatory 'exercise' without sitting at an outdoor table with a strong flat white [coffee] to mark the achievement. I could do it by regulation, but find myself too nervous to do this. The fitness activity minus this small pleasure seems unfinished somehow, though, disturbingly, the seascape in its crisp autumnal beauty looks serene and familiar.

People (on skype, zoom and facetime) reassure me we'll all have more time now for growing vegetables, for household board games, for cleaning out the kitchen cupboards, and, for academics in particular, we'll have the gift of precious time for writing. Enterprising cafes, restaurants and food shops are offering a vigorous program of takeout and home deliveries, as well as donating meals to those out of work. These are all admirable activities and I don't want to sound selfish at a time when people are really struggling not only with the risk of disease but also with a loss of income, homelessness, disability and poverty. Nonetheless, I want my life back, even while acknowledging its privilege.

I have enough food. However, I miss particular foods, particular rituals attached to shopping, cooking, eating and eating out, and miss the intimacy of non-screen mediated moments of 'eating together' (Duruz and Khoo 2015). There is an emotional absence that I expect the newly impoverished are feeling as well as those lucky enough still to have an income. Eating is, after all, about emotional sustenance as well as physical survival, crucial as the latter is. The suffering hospitality industries, together with the many congenial people who work in them, meant so much more to us than mere nutrition. So did the homecooked meals shared with friends. That is why at a time when primarily we fear we'll have to mourn loved ones, or face the risk of job losses, we also feel grief for a lost way of life.

\section{References}

City of West Torrens 2016, City of West Torrens Community Profile. Online, available: https://profile.id.com.au/westtorrens/ancestry?WebID=10 [Accessed 2 April 2020]. 
Duruz, J. \& Khoo, G. C. 2015, Eating Together: Food, Space and Identity in Malaysia and Singapore. Lanham ML: Brown and Littlefield. https://doi.org/10.1017/S1598240800009152

Farm Online. 2020, Farmers Tell Australia: We've Got Your Back. 6 April. Online, available: https://www.farmonline.com. au/story/6714016/farmers-tell-australia-weve-got-your-back-video/?cs=2603 [Accessed 13 November 2020].

Proust, M. 1988-1990, À la Recherche du Temps Perdu. 7 vols., Paris, Gallimard.

Special Broadcasting Service. 2013, 'About Modern Australian Food,' SBS Food, 16 September. Online, available: http:// www.sbs.com.au/food/article/2008/07/01/about-modern-australian-food [Accessed 28 February 2020].

Sky News. 2020, 'Just Stop It: Crazed Coronavirus Hoarders Slammed by the Prime Minister.' Sky Nerws, 18 March. Online, available: https://www.skynews.com.au/details/ 6142425073001 [Accessed 2 April 2020]. 